\title{
DISPARITAS PERLINDUNGAN KEBEBASAN BEREKSPRESI DALAM PENERAPAN PASAL PENGHINAAN UNDANG-UNDANG INFORMASI DAN TRANSAKSI ELEKTRONIK
}

\author{
Kajian Atas Putusan Pengadilan Periode Tahun 2010-2016
}

\section{DISPARITY FREEDOM OF EXPRESSION PROTECTION IN THE IMPLEMENTATION OF DEFAMATION ARTICLE IN INFORMATION AND TRANSACTION ELECTRONIC LAW}

\author{
An Analysis of Court Decisions Year 2010-2016 Period
}

\author{
Vidya Prahassacitta \& Batara Mulia Hasibuan \\ Jurusan Hukum Bisnis, Fakultas Humaniora Universitas Bina Nusantara \\ Kampus Kijang, Jl. Kemanggisan Ilir III No. 45 Palmerah Jakarta 11480 \\ Email: vidya@prahassacitta.com dan batarahsb@yahoo.com
}

Naskah diterima: 15 Januari 2018; revisi: 10 April 2019; disetujui: 2 Mei 2019

http://dx.doi.org/10.29123/jy.v12i1.299

\begin{abstract}
ABSTRAK
Pasal penghinaan dalam Undang-Undang Nomor 11 Tahun 2008 tentang Informasi dan Transaksi Elektronik sebagaimana telah diamandemen dengan UndangUndang Nomor 19 Tahun 2016 merupakan pasal yang sering menimbulkan perdebatan. Penulis mengkaji putusan-putusan pengadilan periode tahun 2010-2016, dan menemukan rumusan masalah bagaimana disparitas penerapan pasal penghinaan dalam Pasal 27 ayat (3) jo. Pasal 45 Undang-Undang Informasi dan Transaksi Elektronik, dan pada aspek perlindungan terhadap kebebasan berekspresi? Penelitian menggunakan metode penelitian normatif dengan pendekatan undang-undang dan pendekatan kasus dilakukan untuk memperoleh jawaban. Analisis terhadap dua belas putusan pengadilan yang telah berkekuatan hukum tetap pada periode tahun 2010 sampai dengan 2016 diperoleh dua kesimpulan. Pertama, terjadi disparitas dalam penerapan Pasal 27
\end{abstract}

ayat (3) jo. Pasal 45 tersebut karena adanya disparitas ketika hakim menginterpretasikan unsur-unsur pasal tersebut. Kedua, terjadi disparitas dalam perlindungan kebebasan berekspresi akibat adanya disparitas tersebut, bahkan penerapan pasal tindak pidana penghinaan tersebut cenderung mengancam kebebasan berekspresi.

Kata kunci: tindak pidana, penghinaan, kebebasan berekspresi.

\section{ABSTRACT}

Article of defamation in Law Number 11 of 2008 on Information and Electronic Transactions as amended by Law Number 19 of 2016 is every so often debated. This analysis examines court decisions around the period 2010-2016 with the formulation of the problem of how inconsistent the application of the defamation article in Article 27 paragraph (3) juncto Article 45 of 
Information and Electronic Transactions Law, along with the aspect of freedom of expression protection. This study uses normative research methods with law and cases approach to obtain answers. Out from analyzing twelve court decisions with have permanent legal force from 2010 to 2016, two conclusions are obtained. First, there is disparity in the application of Article 27 paragraph (3) in conjunction with Article 45 because of the disparity when the judge interprets the elements of the article. Second, there is disparity in the protection of freedom of expression due to the difference; even the application of the criminal offense article tends to threaten freedom of expression. The contradiction must be between the decisions of the same court, or at the same level.

Keywords: criminal act, defamation, freedom of expression.

\section{PENDAHULUAN}

\section{A. Latar Belakang}

Pasal penghinaan dalam Undang-Undang Nomor 11 Tahun 2008 tentang Informasi dan Transaksi Elektronik sebagaimana telah diamandemen dengan Undang-Undang Nomor 19 Tahun 2016 (Undang-Undang Informasi dan Transaksi Elektronik) merupakan pasal yang sering menimbulkan perdebatan. Berdasarkan penelitian sebelumnya, keberadaan pasal mengenai tindak pidana penghinaan dalam Undang-Undang Informasi dan Transaksi Elektronik tersebut tidak memiliki perspektif perlindungan terhadap kebebasan berekspresi (Anggara et al., 2016: 1).

Rumusan delik dalam Pasal 27 ayat (3) jo. Pasal 45 Undang-Undang Informasi dan Transaksi Elektronik dipandang tidak jelas sehingga dapat memidana orang yang hendak menyampaikan ekspresi maupun kritik melalui sarana internet maupun sosial media. Akan tetapi Mahkamah Konstitusi tidak berpendapat demikian, dalam Putusan Nomor 50/PUU-VI/2008 dan Nomor 2/PUU-VII/2009 menyatakan bahwa ketentuan Pasal 27 ayat (3) Undang-Undang Informasi dan Transaksi Elektronik konstitusional dan tidak bertentangan dengan kebebasan berekspresi warga negara. Dalam pertimbangan hukumnya majelis hakim konstitusi memberikan penjelasan mengenai ketentuan Pasal 27 ayat (3) jo. Pasal 45 Undang-Undang Informasi dan Transaksi Elektronik tersebut. Kemudian amandemen Undang-Undang Informasi dan Transaksi Elektronik tahun 2016 mengakomodir poinpoin yang menjadi pertimbangan hukum majelis hakim konstitusi tersebut.

Praktiknya terdapat permasalahan dalam penerapan Pasal 27 ayat (3) jo. Pasal 45 UndangUndang Informasi dan Transaksi Elektronik tersebut. Delapan putusan pengadilan pasca dikeluarkannya Putusan Mahkamah Konstitusi Nomor 50/PUU-VI/2008 dan Nomor 2/PUUVII/2009 menyatakan terdakwa bersalah melanggar ketentuan Pasal 27 ayat (3) jo. Pasal 45 Undang-Undang Informasi dan Transaksi Elektronik. Adapun duduk perkara dan putusan pengadilan tersebut adalah sebagai berikut: 
Tabel 1. Putusan Pengadilan Atas Pasal 27 ayat (3) jo. Pasal 45 Undang-Undang Informasi dan Transaksi Elektronik yang Menghukum Terdakwa

\section{Putusan dan Duduk Perkara}

Kasus ini bermula dari email atau surat elektronik yang dibuat oleh terdakwa PM yang berisi pengalamannya saat dirawat di unit gawat darurat RSOI pada 7 Agustus 2008. Email itu berisi keluhannya atas pelayanan yang diberikan oleh RSOI dan juga dokter yang merawatnya yaitu dr. HG dan dr. GHYN dengan judul email "Penipuan Omni International Hospital Alam Sutra Tanggerang."

Email tersebut antara lain berisikan "Saya informasikan juga dr. HG praktik di RSCM juga. Saya tidak mengatakan RSCM buruk, tetapi hatihati dengan perawatan medis dokter ini dan tanggapan dr. GHYN yang katanya adalah penanggung jawab masalah complaint saya ini tidak profesional sama sekali dan tidak ada sopan santun dan etika mengenai pelayanan.” Email PM ini rupanya sampai ke manajemen RSOI, dan mengambil langkah cepat dengan melaporkan terdakwa tersebut ke polisi dan mengajukan gugatan perdata mengenai pencemaran nama baik.

Bermula dari akunTwitter@ovili yang menyatakan bahwa SM bukan korupsi melainkan merampok. Hal ini kemudian ditanggapi terdakwa BH melalui akunnya @benhan dengan suatu pernyataan yang menunjukkan ironisme karena Mbk termasuk orang yang merampok Bank Century dan dihukum penjara dalam kasus pencairan kredit Bank Century, tetapi dibilang sebagai pembongkar kasus Bank Century. Pada tanggal 8 Desember 2012, Mbk melalui akun Twitter@misbakhun mengirimkan tweet balasan yang pada intinya meminta penjelasan mengenai pernyataan yang mengatasnamakan dirinya sebagai perampok Bank Century dan pembuat akun anonim penyebar karena berdasarkan putusan peninjauan kembali, Mahkamah Agung telah menyatakan bahwa Mbk tidak terbukti melakukan tindak pidana dan membebaskan Mbk dari semua dakwaan tersebut. Terdakwa melalui akun@benhan sudah mengklarifikasi dan tetap pada pernyataan sebelumnya. Mbk melaporkan terdakwa kepada Polda Metro Jaya.

Terdakwa FSS dalam akun Path miliknya menuliskan sebagai berikut:

"Jogja miskin, Tolol dan Tak Berbudaya, teman teman Jakarta-Bandung jangan mau tinggal di Jogja."

“Orang Jogja Bangsat. Kakak mau beli Pertamax 95 mentang-mentang pake motor harus ngantri di jalur mobil terus tidak dilayani malah harus antri di jalur motor yang stuck panjangnya gak ketulungan. Diskriminasi. Emangnya aku gak bisa bayar apa. Huh. KZL.”

Terdakwa AS alias MFMS membuat rekaman video dengan menggunakan kamera handphone miliknya, rekaman video tersebut berisi rekaman diri terdakwa sendiri dengan posisi berdiri mengucapkan kata-kata yang pada intinya sebagai berikut:

"Aku peringatkan kepada presiden RI dan ketua MUI pusat untuk segera masuk agama Islam yang sebenarnya, dengan cara memenuhi dan mengerjakan akad syahadat yang sudah ditetapkan Allah hukum-hukum dalam kitab suci Al Quran dan aku perintahkan untuk menghentikan program ibadah Haji pergi ke tanah haram masjidil haram, Allah menjadikan ka'bah rumah haram sebagai tempat ibadah bagi seluruh umat manusia dan Allah mengharamkan binatang ternak dijadikan korban persembahan kepada ka'bah batu berhala itu dan apapun bentuknya yang telah diharamkan allah hukumnya adalah di larang."

Selanjutnya beberapa hari kemudian video tersebut diunggah ke situs jejaring sosial Youtube dengan judul "ka'bah hanya sebuah batu berhala, jasmerah identitas negaraku dan jagonya Indonesia.'
Putusan Nomor 1333/Pid.Sus/2013/PN.JKT. SEL menyatakan terdakwa secara sah dan meyakinkan terbukti bersalah melakukan penghinaan/pencemaran nama baik sebagaimana dimaksud dalam Pasal 27 ayat (3) jo. Pasal 45 Undang-Undang Nomor 11 Tahun 2008.

Putusan Nomor 382/Pid.Sus/2014/Pn. Yky menyatakan terdakwa secara sah dan meyakinkan terbukti bersalah melakukan penghinaan/pencemaran nama baik sebagaimana dimaksud dalam Pasal 27 ayat (3) jo. Pasal 45 Undang-Undang Nomor 11 Tahun 2008.

Putusan Nomor 33/PID.B/2014/PN.DPU menyatakan terdakwa secara sah dan meyakinkan terbukti bersalah melakukan penghinaan/pencemaran nama baik sebagaimana dimaksud dalam Pasal 27 ayat (3) jo. Pasal 45 Undang-Undang Nomor 11 Tahun 2008. 
Terdakwa FR ikut dalam grup di sosial media Line IKA SALIS 99 dan dalam grup tersebut terdakwa menuliskan yang ditujukan kepada IYL selaku Bupati Kabupaten Gowa sebagai berikut:

"Saya setuju Gowa tidak inovatif, money oriented, power legacy...... arrrrrrrrhhhhhh......tenakabajikang......jai jai investor andak jadi proyekka" dan "Kalau yang bilang Bupati Gowa bagus, kalau bukan keluarganya, antek-anteknya, paling orang suka ngisap/penjilat......... puehhhh serta beuhhhh......telatko pii sudahmi kuscreen shoot baru kuprint, besok kupajang di lobi Kantor Bupati, sa kasi tag line Gowa dimanabnag badai."

Tulisan tersebut kemudian sampai kepada kepada IYL dan melaporkan ini kepada polisi.

CAGD menulis status di wall Facebook miliknya pada 6 September 2010. Terdakwa HJJC menulis komentar di wall Facebook itu dengan menyebut pihak ketiga yaitu ASK.

Konten komentar yang ditulis terdakwa adalah menyebut ASK sebagai manusia berkepala dua. Merasa terhina dengan komentar terdakwa, ASK melaporkan terdakwa ke Polisi Resort Buleleng pada tanggal 21 September 2010.

Kasus ini bermula saat IS pada 13 September 2008 mengaku melihat IH berada di suatu gereja di Singapura pada 2007 dengan berpakaian biarawati dan mengenakan asesoris pakaian biarawati Katolik. Lalu IS menulis surat pernyataan yang membenarkan apa yang dilihatnya tersebut. Pernyataan tersebut juga didengar oleh terdakwa DC dan enam orang lainnya. Terdakwa lalu meminta kepada TF untuk dibuatkan media yang dapat diakses oleh pengurus ARIMATEA di Indonesia dan kemudian dibuatkan blog dan diisi beragam informasi termasuk mengisi sebuah posting laporan dengan judul hasil investigasi terhadap IH dengan melampirkan surat pernyataan dari IS. Setelah terdakwa pulang dari safari dakwah di Australia, blog tersebut ternyata dikunjungi banyak pihak sehingga terdakwa dan satu saksi lainnya memutuskan untuk ditutup dan minta bantuan kepada TF untuk menutupnya.

Kasus ini bermula ketika ramai isu pemilu 2014 lalu. Di akun Facebook atas nama RB, terdakwa KMA yang merupakan Koordinator Bidang Pengawasan dan Hubungan Antar Lembaga, Panitia Pengawas Pemilu (Panwaslu) Kota Bima ikut berkomentar tentang dugaan pelanggaran. Belakangan kicauannya di Facebook itu ditanggapi berbeda oleh KPU Kota Bima. Ketua KPU Kota Bima, N melaporkannya ke polisi pada Februari tahun 2014.

Sumber: Dari berbagai putusan pengadilan perkara tindak pidana penghinaan tahun 2010-2016.
Putusan Nomor 324/Pid.B/2014/PN.SGM menyatakan terdakwa secara sah dan meyakinkan terbukti bersalah melakukan penghinaan/pencemaran nama baik sebagaimana dimaksud dalam Pasal 27 ayat (3) jo. Pasal 45 Undang-Undang Nomor 11 Tahun 2008.

\author{
Putusan Nomor 116/PID/2011/PT.DPS \\ menyatakan terdakwa bebas dari semua \\ dakwaan karena tidak terbukti secara \\ sah dan meyakinkan bersalah melakukan \\ tindakan pidana penghinaan.
}

Putusan Nomor 1190/PID.B/2010/PN.TNG menyatakan terdakwa secara sah dan meyakinkan terbukti bersalah melakukan penghinaan/pencemaran nama baik sebagaimana dimaksud dalam Pasal 27 ayat (3) jo. Pasal 45 Undang-Undang Nomor 11 Tahun 2008.

Putusan Nomor 292/Pid.B/2014/PN.Rbi menyatakan terdakwa bebas dari semua dakwaan karena tidak terbukti secara sah dan meyakinkan bersalah melakukan tindakan pidana penghinaan.

\section{Selain kedelapan putusan pengadilan} tersebut, terdapat empat putusan pengadilan mengenai Pasal 27 ayat (3) jo. Pasal 45 UndangUndang Informasi dan Transaksi Elektronik lainnya yang membebaskan terdakwa. Putusan tersebut juga dikeluarkan setelah Mahkamah Konstitusi mengeluarkan Putusan Nomor 50/ PUU-VI/2008 dan Nomor 2/PUU-VII/2009. Keempat putusan tersebut sebagai berikut: 
Tabel 2. Putusan Pengadilan Atas Pasal 27 ayat (3) jo. Pasal 45 Undang-Undang Informasi dan Transaksi Elektronik yang Membebaskan Terdakwa

\section{Putusan dan Duduk Perkara}

Kasus ini bermula dari email atau surat elektronik yang dibuat oleh terdakwa PM yang berisi pengalamannya saat dirawat di unit gawat darurat RSOI pada 7 Agustus 2008. Email itu berisi keluhannya atas pelayanan yang diberikan oleh RSOI dan juga dokter yang merawatnya yaitu dr. HG dan dr. GHYN dengan judu email "Penipuan Omni International Hospital Alam Sutra Tanggerang."

Email tersebut antara lain berisikan "Saya informasikan juga dr. HG praktik di RSCM juga. Saya tidak mengatakan RSCM buruk, tetapi hati-hati dengan perawatan medis dokter ini dan tanggapan dr. GHYN yang katanya adalah penanggung jawab masalah complaint saya ini tidak profesional sama sekali dan tidak ada sopan santun dan etika mengenai pelayanan." Email PM ini rupanya sampai ke manajemen RSOI, dan mengambil langkah cepat dengan melaporkan terdakwa tersebut ke polisi dan mengajukan gugatan perdata mengenai pencemaran nama baik.

Terdakwa EEH seorang ibu rumah tangga di Bantul Yogyakarta yang menuliskan ketidaksenangan atas pemecatan yang dilakukan oleh JJJ terhadap suami terdakwa, AJ di Facebook pada tanggal 13 Maret 2014. Dalam grup Facebook karyawan JJJ, terdakwa menuliskan kalimat sebagai berikut:

"Pak Har baik, yang gak baik itu yang namanya Ayas dan SPV lainnya. Kami rasa dia gak pantas dijadikan pimpinan Jolie Jogja Jewelley. Banyak yang lebay dan masih seperti anak kecil."

DS, pemilik nama panggilan Ayas, selaku supervisor AJ tidak terima dan melaporkan kepada polisi.

Terdakwa MFM disangka sebagai pemilik akun Twitter @,fajriska menulis pernyataan yang di-retweet akun Twitter@TrioMacan2000 sebagai berikut:

"Kasus pembobolan BRI oleh Richard Latief tahun 2004, tapi malah dilepas oleh oknum JKS penyidik yang sekarang sudah jadi Jaksa Agung Muda. Si oknum Jaksa Agung Muda (JAM) tersebut inisialnya ME. Kasus pembobolan BRI tahun 2004 sejumlah $180 \mathrm{M}$ tapi si JAM menyita lebih dari 500M justru disedot semua rekening-rekening tersangka yang di luar dari aliran dana pembobolan."

Jaksa Agung Muda, ME kemudian merasa dirugikan menganggap bahwa akun@ fajriksa dan akun@TrioMacan2000 dimiliki oleh terdakwa serta melaporkan kedua akun tersebut kepada polisi.

Terdakwa MA dalam status Black Berry Messenger menulis "No Fear Nurdin Halid Koruptor!!! Jangan pilih adik koruptor!!!” Terdakwa dilaporkan ke polisi oleh AW, anggota Dewan Perwakilan Rakyat Daerah (DPRD) Kota Makassar dari Partai Golongan Karya.

\section{Putusan Pengadilan}

Putusan Nomor 1269/Pid.B/2009/

PN.TNG menyatakan terdakwa bebas dari semua dakwaan karena tidak terbukti secara sah dan meyakinkan bersalah melakukan tindakan pidana penghinaan.
Putusan Nomor 196/Pid.sus//2014/ PN.BTL menyatakan terdakwa bebas dari semua dakwaan karena tidak terbukti secara sah dan meyakinkan bersalah melakukan tindakan pidana penghinaan.
Putusan Nomor 1832/Pid.B/2012/ PN.Jkt.Sel menyatakan terdakwa bebas dari semua dakwaan karena tidak terbukti secara sah dan meyakinkan bersalah melakukan tindakan pidana pengaduan palsu kepada penguasa sebagaimana dimaksud dalam Pasal 317 ayat (1) KUHP.

Putusan Nomor 390/Pid.B/2014/

PN.Mks menyatakan terdakwa

bebas dari semua dakwaan karena tidak terbukti secara sah dan meyakinkan bersalah melakukan tindakan pidana penghinaan.

Sumber: Dari berbagai putusan pengadilan perkara tindak pidana penghinaan tahun 2010-2016.

Adanya putusan yang membebaskan dan memidana terdakwa tersebut menarik untuk diteliti. Pada perkara-perkara yang dipandang memiliki posisi kasus yang serupa namun majelis hakim memberikan putusan yang berbeda. Hal ini merupakan bentuk dari disparitas antara tindak pidana yang dijatuhkan oleh majelis hakim yang berbeda untuk tindak pidana yang sama (KY RI, 2014: 187).
Hal ini menarik untuk diteliti terutama mengenai disparitas dalam interpretasi majelis hakim mengenai unsur-unsur penghinaan dalam Pasal 27 ayat (3) jo. Pasal 45 Undang-Undang Informasi dan Transaksi Elektronik yang menghasilkan inkonsistensi dalam putusanputusan pengadilan (KY RI, 2014: 188). Selanjutnya disparitas ini berkaitan dengan inkonsistensi dalam perlindungan atas kebebasan 
berekspresi para pengguna internet. Oleh karenanya penelitian ini akan juga menggali aspek perlindungan kebebasan berekspresi dari keberadaan dan penerapan dalam Pasal 27 ayat (3) jo. Pasal 45 Undang-Undang Informasi dan Transaksi Elektronik tersebut.

\section{B. Rumusan Masalah}

1. Bagaimana disparitas penerapan pasal penghinaan dalam Pasal 27 ayat (3) jo. Pasal 45 Undang-Undang Informasi dan Transaksi Elektronik terhadap 12 putusan periode tahun 2010-2016?

2. Bagaimana disparitas aspek perlindungan terhadap kebebasan berekspresi dalam 12 putusan periode tahun 2010-2016?

\section{Tujuan dan Kegunaan}

Sesuai dengan latar belakang dan rumusan masalah yang telah dikemukan di atas, penelitian memiliki beberapa tujuan penelitian. Pertama untuk mendeskripsikan dan mencari pemecahan masalah terkait disparitas dalam interpretasi tindak pidana penghinaan dalam Pasal 27 ayat (3) jo. Pasal 45 Undang-Undang Informasi dan Transaksi Elektronik dalam putusan pengadilan dalam periode tahun 2010 sampai dengan tahun 2016. Kedua untuk mendeskripsikan hubungan antara disparitas dalam penerapan Pasal 27 ayat (3) jo. Pasal 45 Undang-Undang Informasi dan Transaksi Elektronik dalam putusan-putusan pengadilan tersebut dengan perlindungan kebebasan berekspresi pengguna internet di Indonesia.

Tulisan ini diharapkan dapat memberikan kontribusi baik secara teoritis kepada dispilin ilmu hukum yang ditekuni oleh penulis maupun kepada para praktisi hukum serta para akademisi dalam menyelesaikan perkara-perkara mengenai penghinaan yang dilakukan secara online. Selain itu penelitian ini juga diharapkan dapat memberikan kontribusi dalam kajian mengenai praktik kebebasan berekspresi melalui sarana online di Indonesia.

\section{Tinjuan Pustaka \\ 1. Kebebasan Berekspresi}

Kebebasan berekspresi atau freedom of expression merupakan bagian dari hak asasi manusia dan merupakan salah satu hak-hak sipil dan politik yang merupakan generasi pertama hak asasi manusia. Hak ini merupakan hak negatif yang mensyaratkan tidak adanya campur tangan dari negara atas hak-hak dan kebebasan individu tersebut (Smith et al., 2008: 25). Pengertian freedom of expression mencangkup konsep freedom of press dan freedom of speech (Prahassacitta, 2017: 49).

Jaminan akan kebebasan berekspresi telah dinyatakan dalam berbagai konvensi internasional mengenai hak asasi manusia antara lain pada Universal Declaration Human Right dan International Covenant on Civil and Politic Right. Akan tetapi sebagaimana diatur dalam Pasal 19 International Covenant on Civil and Politic Right, kebebasan berekspresi tersebut bersifat restriktif, artinya pendapat hanya dapat dilakukan berdasarkan undang-undang demi menghormati hak, reputasi orang lain, dan dalam rangka melindungi keamanan nasional. Kebebasan berekspresi harus menghormati: (i) hak-hak dan kebebasan orang lain (respects for the rights and freedoms of others); (ii) aturan-aturan moral yang diakui umum (generally accepted moral code); (iii) ketertiban umum (public order); 
(iv) kesejahteraan umum (general walfare); (v) keamanan umum (public safety); (vi) keamanan nasional dan keamanan masyarakat (national and social security); (vii) kesehatan umum (public health); (viii) menghindari penyalahgunaan hak (abuse of right); (ix) asas-asas demokrasi; dan (x) hukum positif (Muladi, 2002: 8-9).

Selain itu berbagai konvensi internasional juga secara tegas mengatur mengenai bentukbentuk kebebasan ekspresi yang dilarang yaitu pornografi anak, seruan untuk mendorong tindakan yang mengarah ke genosida, advokasi kebencian berbasis ras, agama atau kebangsaan yang merupakan ajakan untuk mendiskriminasi, permusuhan atau kekerasan, dan ajakan kepada terorisme.

Indonesia mengakui kebebasan berekspresi sebagai hak dasar warga negara sebagaimana diatur dalam Pasal 28E ayat (3) UUD NRI 1945. Hak tersebut juga secara tegas diatur dalam berbagai undang-undang, salah satunya dalam Pasal 55 Undang-Undang Nomor 39
Tahun 1999 tentang Hak Asasi Manusia. Seperti halnya konvensi internasional yang membatasi kebebasan berekspresi, hukum positif Indonesia juga membatasi bentuk-bentuk kebebasan berekspresi, salah satunya adalah tindak pidana penghinaan terhadap orang lain. Hal ini dipertegas oleh Mahkamah Konstitusi dalam Putusan Nomor 50/PUU-VI/2008 dan Nomor 2/ PUU-VII/2009.

\section{Tindak Pidana Penghinaan}

Penghinaan diartikan sebagai perbuatan yang dengan sengaja menyerang kehormatan dan/atau nama baik orang (Prodjodikoro, 2003: 93). Lebih lanjut yang diserang hanya dapat berupa kehormatan tentang nama baik bukan kehormatan lainnya seperti kehormatan seksual (Soesilo, 1996: 226). Tindak pidana penghinaan yang secara umum diatur dalam Bab XVI Buku II Kitab Undang-Undang Hukum Pidana (KUHP). Terdapat enam bentuk penghinaan sebagai berikut:

Tabel 3. Jenis-Jenis Penghinaan dalam KUHP

\begin{tabular}{|c|c|c|}
\hline Pasal & Jenis & Rumusan Pasal \\
\hline \multirow[t]{2}{*}{310} & $\begin{array}{l}\text { Penghinaan } \\
\text { (belediging/smaad) }\end{array}$ & $\begin{array}{l}\text { (1) Barang siapa sengaja menyerang kehormatan atau nama baik seseorang } \\
\text { dengan menuduhkan sesuatu hal, yang maksudnya terang supaya hal itu } \\
\text { diketahui umum, diancam karena menista dengan pidana penjara paling } \\
\text { lama sembilan bulan atau pidana denda paling banyak empat ribu lima } \\
\text { ratus rupiah. }\end{array}$ \\
\hline & & $\begin{array}{l}\text { (2) Jika hal itu dilakukan dengan tulisan atau gambaran yang disiarkan, } \\
\text { dipertunjukkan atau ditempelkan di muka umum, maka diancam karena } \\
\text { menista tertulis dengan pidana penjara paling lama satu tahun empat } \\
\text { bulan atau pidana denda paling banyak empat ribu lima ratus rupiah. }\end{array}$ \\
\hline 311 & Memfitnah (laster) & $\begin{array}{l}\text { Jika yang melakukan kejahatan menista atau menista tertulis dibolehkan untuk } \\
\text { membuktikan apa yang dituduhkan itu benar, tidak membuktikannya, dan } \\
\text { tuduhan dilakukan bertentangan dengan apa yang diketahui, maka dia diancam } \\
\text { melakukan fitnah dengan pidana penjara paling lama empat tahun. }\end{array}$ \\
\hline 315 & $\begin{array}{l}\text { Penghinaan bersahaja } \\
\text { (eenvoudige belediging) }\end{array}$ & $\begin{array}{l}\text { Tiap-tiap penghinaan dengan sengaja yang tidak bersifat pencemaran atau } \\
\text { pencemaran tertulis yang dilakuknn terhadap seseorang, baik di muka umum } \\
\text { dengan lisan atau tulisan, maupun di muka orang itu sendiri dengan lisan atau } \\
\text { perbuatan, atau dengan surat yang dikirimkan atau diterimakan kepadanya, } \\
\text { diancam karena penghinaan ringan dengan pidana penjara paling lama empat } \\
\text { bulan dua minggu atau pidana denda paling banyak empat ribu lima ratus rupiah. }\end{array}$ \\
\hline
\end{tabular}




\begin{tabular}{lll}
\hline 317 & $\begin{array}{l}\text { Pengaduan yang } \\
\text { bersifat memfitnah } \\
\text { (lasterlijke aanklacht) }\end{array}$ & $\begin{array}{l}\text { Barang siapa dengan sengaja mengajukan pengaduan atau pemberitahuan } \\
\text { palsu kepada penguasa, baik secara tertulis maupun untuk dituliskan, tentang } \\
\text { seseorang sehingga kehormatan atau nama baiknya terserang, diancam karena } \\
\text { melakukan pengaduan fitnah, dengan pidana penjara paling lama empat tahun. }\end{array}$ \\
\hline 318 & $\begin{array}{l}\text { Perbuatan yang bersifat } \\
\text { memfitnah (lasterlijke } \\
\text { verdacht making) }\end{array}$ & $\begin{array}{l}\text { Barang siapa dengan sesuatu perbuatan sengaja menimbulkan secara palsu } \\
\text { persangkaan terhadap seseorang bahwa dia melakukan suatu perbuatan pidana, } \\
\text { diancam karena menimbulkan persangkaan palsu, dengan pidana penjara paling } \\
\text { lama empat tahun. }\end{array}$ \\
\hline 320 & $\begin{array}{l}\text { Penistaan terhadap } \\
\text { orang yang telah } \\
\text { meninggal }\end{array}$ & $\begin{array}{l}\text { Barang siapa terhadap seseorang yang sudah mati melakukan perbuatan yang } \\
\text { kalau orang itu masih hidup akan merupakan pencemaran atau pencemaran } \\
\text { tertulis, diancam dengan pidana penjara paling lama empat bulan dua minggu } \\
\text { atau pidana denda paling banyak empat ribu lima ratus rupiah. }\end{array}$ \\
\hline
\end{tabular}

Sumber: KUHP.

Jika melihat rumusan dalam KUHP, terdapat tiga istilah berbeda yang dipergunakan yaitu penghinaan, penistaan, dan fitnah. Ketiganya memiliki pengertian yang berbeda. Penghinaan dapat diartikan sebagai menyerang kehormatan dan nama baik seseorang dengan menuduhkan sesuatu hal supaya hal tersebut diketahui oleh umum dengan cara lisan. Tindak pidana penghinaan diatur dalam Pasal 310 ayat (1) KUHP. Penistaan sama seperti penghinaan namun caranya dilakukan melalui tulisan dan/ atau gambar.

Tindak pidana penistaan diatur dalam Pasal 310 ayat (2) KUHP. Sedangkan fitnah, perbuatannya sama seperti penistaan yaitu menyerang kehormatan dan nama baik seseorang dengan menuduhkan sesuatu hal supaya hal tersebut diketahui oleh umum dengan cara tertulis dan/atau gambar akan tetapi orang yang melakukan penyerangan tersebut tidak dapat membuktikan pernyataanya. Tindak pidana fitnah diatur dalam Pasal 311 ayat (1) KUHP.

Selain dalam KUHP, tindak pidana penghinaan juga diatur dalam Pasal 27 ayat (3) jo. Pasal 45 Undang-Undang Informasi dan Transaksi Elektronik. Pasal tersebut telah mengalami amandemen ketika Undang-Undang Informasi dan Transaksi Elektronik diamandemen pada tahun 2016 lalu. Perubahan ketentuan tersebut adalah sebagai berikut:

Tabel 4. Perbandingan Ketentuan Pencemaran Nama Baik

\begin{tabular}{|c|c|}
\hline $\begin{array}{c}\text { Undang-Undang Informasi dan Transaksi Elektronik } \\
\text { Tahun } 2008\end{array}$ & $\begin{array}{c}\text { Undang-Undang Informasi dan Transaksi Elektronik } \\
\text { Tahun } 2016\end{array}$ \\
\hline Pasal 27 ayat $(3)$ & Pasal 27 ayat $(3)$ \\
\hline $\begin{array}{l}\text { Setiap orang dengan sengaja dan tanpa hak } \\
\text { mendistribusikan dan/atau mentransmisikan dan/atau } \\
\text { membuat dapat diaksesnya informasi elektronik dan/atau } \\
\text { dokumen elektronik yang memiliki muatan penghinaan } \\
\text { dan/atau pencemaran nama baik. }\end{array}$ & $\begin{array}{l}\text { Ketentuan Pasal } 27 \text { ayat (3) tetap seperti dalam Undang- } \\
\text { Undang Nomor } 11 \text { Tahun } 2008 .\end{array}$ \\
\hline Penjelasan Pasal 27 ayat (3): & Penjelasan Pasal 27 ayat (3): \\
\hline Cukup jelas & $\begin{array}{l}\text { Ketentuan pada ayat ini mengacu pada ketentuan } \\
\text { pencemaran nama baik dan/atau fitnah yang diatur dalam } \\
\text { KUHP. }\end{array}$ \\
\hline
\end{tabular}


Pasal 45 ayat (1):

Setiap orang yang memenuhi unsur sebagaimana dimaksud dalam Pasal 27 ayat (1), ayat (2), ayat (3) atau ayat (4) dipidana dengan pidana penjara paling lama enam tahun dan/atau denda paling banyak Rp1.000.000.000,- (satu miliar rupiah).

Pasal 45 ayat (3):

Setiap orang yang dengan sengaja dan tanpa hak mendistribusikan dan/atau mentransmisikan dan/atau membuat dapat diaksesnya informasi elektronik dan/atau dokumen elektronik yang memiliki muatan penghinaan dan/atau pencemaran nama baik sebagaimana dimaksud dalam Pasal 27 ayat (3) dipidana dengan pidana penjara paling lama empat tahun dan/atau denda paling banyak Rp750.000.000,- (tujuh ratus lima puluh juta rupiah).

Pasal 45 ayat (5):

Ketentuan sebagaimana dimaksud pada ayat (3) merupakan delik aduan.

Penjelasan Pasal 45 ayat (1): Penjelasan Pasal 45 Ayat (3) dan (5)

Cukup jelas.

Cukup jelas.

Sumber: Undang-Undang Informasi dan Transaksi Elektronik Tahun 2008 dan Tahun 2016.

Dalam rumusan Pasal 27 ayat (3) jo. Pasal 45 Undang-Undang Informasi dan Transaksi Elektronik, tindak pidana penghinaan disamakan dengan tindak pidana pencemaran nama baik, padahal keduanya berbeda. Perbuatan pencemaran nama baik merupakan bagian dari bentuk penghinaan yang secara umum. Dalam common law dikenal istilah libel dan slander di mana libel yang dalam bahasa Indonesia disepadankan dengan pencemaran nama baik, dan slander disepadankan dengan penistaan.

Baik libel dan slander merupakan suatu defamatory statement atau pernyataan penghinaan yaitu suatu bentuk pernyataan-pernyataan mengenai seseorang yang membawa dampak bahwa orang tersebut dalam kebencian (hatred), ejekan atau cemoohan (ridicule) atau pencemaran (contempt). Keduanya hanya berbeda pada mediumnya. Jika libel mediumnya dilakukan dalam media tertulis baik yang berbentuk permanen. Slander kata-katanya disampaikan secara lisan atau atas significant gesture.

Perbedaan ini membawa pada tanggung jawab yang berlainan karena libel dipandang sebagai pelanggaran yang lebih serius dari pada slander. Selain itu jangka waktu kedaluwarsa pada pernyataan dengan menggunakan media tertulis memiliki tenggang waktu yang berbeda dengan slander (Prahassacitta, 2017: 49). Dalam KUHP, libel yang merupakan penistaan tertulis diatur dalam Pasal 310 ayat (2) KUHP, dan slander yang merupakan pencemaran lisan diatur dalam Pasal 310 ayat (1) KUHP.

Bentuk penghinaan mengalami perkembangan. Semula penghinaan hanya diartikan secara terbatas dalam bentuk penghinaan formal saja atau formeele belediging, di mana bentuk penghinaan menurut caranya yang ditempuh sehingga suatu pernyataan yang tegas dan jelas caranya kasar. Contoh penghinaan formal adalah ketika A dan B yang sama-sama merupakan pegawai negeri kemudian terlibat dalam pertengkaran, kemudian A mengeluarkan kata-kata yang menyatakan bahwa "B koruptor kakap."

Perkembangan penghinaan di Belanda kemudian berkembang menjadi penghinaan materiel atau materiale belediging yaitu suatu bentuk penghinaan yang menurut isinya dan dilihat dari keadaan-keadaan yang melatarbelakanginya adalah suatu penghinaan yang dilakukan secara halus. Contohnya A yang merupakan seorang pemimpin menanyakan kepada B yang merupakan 
bawahannya tentang adanya korupsi berupa kebocoran uang anggaran bagi penyelenggaraan seminar dengan menanyakan "baik juga pertanggungjawaban yang anda (B) berikan kepada saya!" Pertanyaan itu jelas mengandung suatu tuduhan bahwa B telah melakukan korupsi dalam penyelenggaraan seminar tersebut dan hal ini yang dinamakan dengan penghinaan materiel. Demikian dalam KUHP Indonesia yang merupakan hasil konkordansi dari $W v S$ Nederland (KUHP Belanda), maka pengertian penghinaan juga tidak terbatas pada penghinaan formal juga tetapi juga meliputi penghinaan materiel (Adji, 2001: 60-61).

\section{METODE}

Metode penelitian yang digunakan dalam tulisan ini adalah yuridis normatif dengan menggunakan pendekatan undang-undang dan pendekatan kasus. Keduanya merupakan bentuk yang lazim dipergunakan dalam penelitian normatif hokum, hal tersebut tidak dapat dipisahkan dari pengertian normatif dalam arti sebagai undang-undang dan norma sebagai undang-undang yang diimplementasikan atau dikonkretkan dalam putusan pengadilan.

Pendekatan undang-undang yang dipergunakan dengan melihat muatan-muatan norma pada undang-undang yang ada, latar belakang lahirnya norma dalam undang-undang tersebut dan kesesuaian antara undang-undang yang satu dengan undang-undang yang lain (Ibrahim, 2013:310). Pendekatan kasus dilakukan dengan melakukan ratio decidendi dalam hal ini menurut Goodheart merupakan fakta-fakta materiel yang diterapkan dalam aturan hukum yang kemudian dijadikan putusan oleh hakim (Mahmud, 2005: 130).
Penelitian mencakup kegiatan penyusunan dan perancangan penelitian, pengumpulan dan pengolahan data serta melakukan analisis terhadap data-data yang telah terkumpul untuk kemudian disusun dalam suatu tulisan penelitian. Data-data yang dipergunakan dalam penelitian ini merupakan data-data yang bersumber dari data sekunder, yaitu data-data yang diperoleh melalui metode penelitian kepustakaan dengan menelaah bahan-bahan kepustakaan atau dengan melakukan studi dokumen, termasuk putusan-putusan pengadilan yang telah berkekuatan hukum tetap.

Terdapat 12 putusan pengadilan yang dipergunakan dalam penelitian ini. Putusan tersebut telah berkekuatan hukum tetap dan merupakan putusan pengadilan dalam kurun waktu tahun 2010 sampai dengan 2016. Pemilihan putusan tersebut didasarkan atas perbuatan penghinaan dilakukan dengan menggunakan sarana online. Dari 12 putusan tersebut terdiri dari delapan putusan yang menghukum terdakwa, dan empat putusan yang membebaskan terdakwa. Penelitian dilakukan dengan menjabarkan dan menganalisis interpretasi masing-masing unsur dalam Pasal 27 ayat (3) jo. Pasal 45 UndangUndang Informasi dan Transaksi Elektronik, kemudian membandingkan unsur-unsur tersebut antara putusan-putusan yang menghukum dan yang membebaskan, dengan tujuan untuk mengetahui perbedaan interpretasi tersebut dan menganalisis ancaman terhadap kebebasan berekspresi dari putusan tersebut.

\section{HASIL DAN PEMBAHASAN}

A. Disparitas dalam Interpretasi UnsurUnsur Pasal 27 ayat (3) jo. Pasal 45 Undang-Undang Informasi dan Transaksi Elektronik dalam Putusan Pengadilan 
Pasal 27 ayat (3) jo. Pasal 45 UndangUndang Informasi dan Transaksi Elektronik memiliki empat unsur yaitu: (i) setiap orang; (ii) dengan sengaja dan tanpa hak; (iii) mendistribusikan dan/atau mentransmisikan dan/atau membuat dapat diaksesnya informasi elektronik dan/atau dokumen elektronik; dan (iv) yang memiliki muatan penghinaan dan/atau pencemaran nama baik. Dalam putusan-putusan tersebut terdapat disparitas atas penerapan unsur pertama, kedua, ketiga, dan keempat dari tindak pidana penghinaan tersebut sebagai berikut:

\section{Unsur dengan Sengaja dan Tanpa Hak}

Kesengajaan yang dimaksud adalah kesengajaan untuk melakukan perbuatan mendistribusikan, mentransmisikan maupun membuat dapat diakses suatu data atau informasi elektronik secara melawan hukum. Berdasarkan teori kesengajaan, pelaku tindak pidana harus memiliki dua elemen, yaitu volitief (kehendak) dan intelektual (pengetahuan), oleh karenanya setiap tindakan yang dilakukan secara sengaja harus selalu dikehendaki atau willens dan disadari atau diketahui (wetens) (Remmelink, 2003: 152).

Hal ini pelaku harus memiliki pengetahuan dan kehendak untuk mendistribusikan, mentransmisikan, maupun membuat dapat diakses suatu data atau informasi elektronik secara melawan hukum. Khusus untuk tindak pidana penghinaan dalam praktik dan yurispudensi berkembang ajaran animus injuriandi, yang cukup mensyaratkan adanya kesadaran atau pengetahuan pelaku bahwa pernyataannya yang objektif akan berakibat atau dapat menyerang kehormatan atau nama baik orang lain. Jadi pelaku sudah dapat dipidana walaupun tujuan utama pelaku bukan untuk menghina atau tidak adanya kesengajaan untuk menghina, karena penghinaan sudah timbul sebagai akibat dari pernyataan lisan atau pun tertulis tersebut (Adji, 2008: 62-63).

Interpretasi berbeda mengenai unsur kesengajaan dalam bentuk dolus eventualis/opzet bij mogelijkheid-bewustzijn dalam tiga putusan pengadilan. Majelis hakim menggunakan ajaran animus injuriandi pada Putusan Nomor 324/Pid.B/2014/PN.SGM dan Nomor 822K/ Pid.Sus/2010, sehingga para pelaku yang memiliki unsur kesengajaan dalam bentuk dolus eventualis/opzet bij mogelijkheid-bewustzijn tetap dapat dipidana. Menurut doktrin dolus eventualis/opzet bij mogelijkheid-bewustzijn merupakan bentuk kesengajaan di mana pelaku sesungguhnya tidak menghendaki akibatnya, namun perbuatan tersebut tetap dilakukan sehingga pelaku tersebut tetap harus menanggung risiko yang timbul (Hiariej, 2014: 138). Elemen kehendak atau willens masih tetap ada walaupun dalam degradasi yang sangat rendah.

Dalam Putusan Nomor 324/Pid.B/2014/ PN.SGM, perbuatan terdakwa FR yang menuliskan kalimat berupa pendapat dan kritik terhadap Bupati Gowa di grup sosial media telah memenuhi unsur kesengajaan meskipun di dalam grup tersebut tidak terdapat Bupati Gowa sebagai anggotanya, namun majelis hakim berpandangan bahwa apa yang terdakwa tuliskan tersebut dapat menyebar ke luar grup dan berakibat pada serangan terhadap nama baik Bupati Gowa.

\section{Dalam Putusan Nomor 822K/Pid.} Sus/2010, perbuatan terdakwa PM yang menyebarkan keluhannya mengenai pelayanan dokter dan RSOI melalui email kepada temantemannya memang tidak bertujuan untuk 
menyerang nama baik pribadi dokter tersebut, akan tetapi terdakwa seharusnya menyadari bahwa apa yang ia tuliskan tersebut bukan dilakukan sesuai prosedur. Berbeda dengan Putusan Nomor 196/Pid.sus//2014/PN.BTL, majelis hakim mengabaikan ajaran animus injuriandi meskipun perbuatan terdakwa EEH merupakan pencerminan dari kesengajaan dalam bentuk dolus eventualis/opzet bij mogelijkheidbewustzijn karena apa yang dilakukan oleh terdakwa EEH hanya menyampaikan keluh kesahnya saja di media sosial Facebook.

Kemudian unsur melawan hukum dalam Pasal 27 ayat (3) jo. Pasal 45 Undang-Undang Informasi dan Transaksi Elektronik tercermin dari kata tanpa hak. Dalam hal ini pernyataan lisan atau tertulis seperti apa yang dipandang sebagai perbuatan melawan hukum sehingga dapat dikategorikan sebagai penghinaan. Sesuai dengan Putusan Mahkamah Konstitusi Nomor 50/PUU-VI/2008 dan Nomor 2/PUU-VII/2009, ketentuan penghinaan dalam Undang-Undang Informasi dan Transaksi Elektronik tidak dapat dilepaskan dari Pasal 310 dan 311 KUHP sebagai genus crime-nya. Oleh karenanya perbuatan yang tidak bisa dikategorikan sebagai melawan hukum hanya apabila dilakukan untuk kepentingan umum, sedangkan menyampaikan pendapat, kritik atau keluh kesah melalui email atau di sosial media milik pribadi para terdakwa masih menjadi tanda tanya.

Bercermin pada Putusan Nomor 822K/ Pid.Sus/2010 di mana seharusnya penyampaian keluhan atas pelayanan rumah sakit atau dokter seharusnya dilakukan melalui mekanisme laporan ke MKDKI, maka unsur melawan hukum berbicara mengenai cara atau media dalam menyampaikan kritik, pendapat atau keluh kesah tersebut. Untuk penyampaian kebebasan ekspresi yang tidak memiliki jalur formal, hal ini masih menjadi pertentangan. Dalam Putusan Nomor 324/Pid.B/2014/PN.SGM perbuatan menyampaikan pendapat, kritik atau keluh kesah melalui email atau di sosial media milik pribadi terdakwa dikategorikan sebagai perbuatan yang melawan hukum. Berbeda dengan Putusan Nomor 196/Pid.sus//2014/PN.BTL, perbuatan terdakwa yang menyampaikan keluh kesahnya di media sosial Facebook bukanlah perbuatan melawan hukum sehingga perbuatan terdakwa tersebut tidak dapat dikategorikan sebagai pencerminan dari adanya niat jahat.

\section{Unsur Mendistribusikan dan/atau Mentransmisikan dan/atau Membuat Dapat Diaksesnya Informasi Elektronik dan/atau Dokumen Elektronik}

Pertimbanganhukum MahkamahKonstitusi dalam Putusan Nomor 50/PUU-VI/2008 dan Nomor 2/PUU-VII/2009, menyatakan bahwa unsur "di muka umum" atau "diketahui umum" secara tidak langsung telah tersirat dalam unsur "mendistribusikan" dan/atau "mentrasmisikan" dan/atau "membuat dapat diakses" pada Pasal 27 ayat (3) jo. Pasal 45 Undang-Undang Informasi dan Transaksi Elektronik.

Majelis hakim konstitusi berpandangan bahwa unsur "di muka umum" atau "diketahui umum" dalam KUHP tidak tepat atau kurang memadai perbuatan yang bersifat siber sehingga diperlukan rumusan khusus yang bersifat ekstensif dalam kata atau unsur "mendistribusikan" dan/ atau "mentrasmisikan" dan/atau "membuat dapat diakses." Oleh karenanya perbuatan menghina atau mencemarkan nama baik harus dilakukan dengan tujuan untuk diketahui umum dengan melakukan perbuatan di muka umum. 
Hadirnya media sosial menjadi permasalahan tersendiri terutama mengenai mana yang masuk dalam ruang privat dan ruang publik. Karakteristik sosial media yang partisipasi (participation), keterbukaan (openness), komunikasi (conversation), komunitas (community), dan keterhubungan (connectedness) (Chan-Olmsted, Cho \& Lee, 2013: 154-156), membuat penggunanya akan lebih mudah menyampaikan pendapatnya dan membuat pendapat lebih mendemokrasi karena perkembangan teknologi memungkinkan diterima bagi masyarakat luas (Balkin, 2004: 1).

Sosial media membuat batas-batas ruang privat dan publik menjadi daerah abu-abu, individu dapat dengan bebas mengekspresikan pendapat maupun emosinya melalui akun sosial media miliknya tanpa menyadari bahwa apa yang ia sampaikan tersebut dapat dengan mudah diketahui orang lain maupun masyarakat.

Jika dikaitkan antara kehadiran sosial media dan Pasal 27 ayat (3) jo. Pasal 45 UndangUndang Informasi dan Transaksi Elektronik, maka hal ini dipandang akan mengkriminalisasi kebebasan berekspresi karena penyampaian pendapat maupun emosi di ranah privat kemudian ditafsirkan sebagai penyampaian di muka publik. Hal ini tercermin dalam beberapa putusan pengadilan yaitu Putusan Nomor 324/Pid.B/2014/ PN.SGM dan Nomor 382/Pid.Sus/2014/Pn.Yky.

Dalamkeduaputusantersebut, para terdakwa menuliskan apa yang menjadi pikiran, pendapat maupun menyampaikan emosinya di akun pribadi sosial media mereka yang tidak dapat diakses oleh publik, sehingga apa yang disampaikan tersebut dalam pandangan penulis masih dalam ranah privat dan tidak masuk dalam kategori di muka umum maupun untuk diketahui umum.
Pada putusan tersebut platform sosial media yang dipergunakan adalah Line Group dan Path yang memiliki lingkup yang terbatas. Kemudian apa yang disampaikan tersebut diketahui umum karena adanya penyebaran atas tulisan yang disampaikan oleh para terdakwa tersebut kepada masyarakat, dan menurut pandangan penulis pihak yang menyebarkan tersebutlah yang harus dimintai pertanggungjawaban karena telah menyebarkan tanpa hak. Dalam kedua putusan tersebut, majelis hakim lebih mengutamakan pada faktor kerugian (harm) yang ditumbulkan dari ekspresi yang disampaikan secara online oleh pada terdakwa.

Putusan lainnya, majelis hakim dapat dengan cermat dan tepat membedakan mana yang masuk dalam ruang privat dan publik. Putusan Nomor 116/PID/2011/PT.DPS, meskipun terdakwa HJJC menyampaikan pendapatnya di wall akun Facebook miliknya, dan tulisan tersebut bisa dibaca oleh orang lain termasuk terlapor ASK, akan tetapi unsur di muka umum atau diketahui umum tidak terpenuhi karena dalam Facebook tersebut terdakwa berteman dengan para jemaat dan pengurus gereja terdakwa. Selain itu apa yang disampaikan oleh terdakwa hanya ditujukan untuk pengurus dan umat gereja tempat terdakwa dan ASK saja.

\section{Unsur Penghinaan dan/atau Pencemaran Nama baik}

Secara rumusan, unsur ini memiliki kerancuan. Pertama, karena dalam unsur ini pembuat undang-undang mencampuradukkan antara tiga perbuatan yang berbeda yaitu penghinaan, pencemaran nama baik, dan fitnah. Kedua, unsur ini tidak jelas karena tidak menguraikan elemen-elemen dari perbuatan penghinaan atau pencemaran nama baik atau 
fitnah itu sendiri, sehingga dalam beberapa putusan pengadilan majelis hakim tidak secara tegas menguraikan perbuatan terdakwa apa saja yang telah memenuhi kualifikasi sebagai penghinaan, pencemaran nama baik atau pun fitnah, seperti dalam Putusan Nomor 1333/Pid. Sus/2013/PN.JKT.SEL atas nama terdakwa BH (Rezaldi, 2015: 33).

Menarik kemudian jika menganalisis tindak pidana penghinaan pada Putusan Nomor 33/PID.B/2014/PN.DPU, di mana ucapan yang disampaikan oleh terdakwa AS. Perkataan yang terdakwa rekam dan diunggah ke sosial media youtube tidak bisa dikualifikasikan sebagai penghinaan. Memang dalam video tersebut terdakwa tidak menyebutkan nama, tetapi hanya menyebutkan Presiden RI dan Ketua MUI yang hal tersebut sudah dapat diasosiasikan kepada orang yang dimaksud. Akan tetapi isi yang disampaikan oleh terdakwa bukanlah bentuk penyerangan terhadap nama baik orang, melainkan sebuah pandangan pribadi terdakwa atas ajaran dan syariat agama Islam yang bertentangan dengan pandangan umum. Dalam pertimbangan hukum, majelis hakim pun tidak dapat menjelaskan adanya unsur-unsur penghinaan dari ucapan terdakwa, namun hanya menyampaikan bahwa apa yang disampaikan oleh terdakwa bertentangan dengan ajaran dan syariat dari agama Islam telah memenuhi unsur yang memiliki muatan penghinaan telah terpenuhi.

Dalam praktik, tidak adanya kualifikasi yang jelas mengenai ucapan, tulisan atau pun gambar apa yang merupakan penghinaan, menyebabkan disparitas dalam putusan-putusan pengadilan. Salah satu indikator yang sering dipergunakan oleh majelis hakim dalam beberapa putusannya adalah penyebutan nama orang yang dihina. Penulis berpandangan bahwa hal ini tidak dapat dipisahkan dari rumusan tindak pidana penghinaan sebagai delik aduan. Pelapor haruslah subjek yang dihina atau dicemarkan nama baiknya atau difitnah, harus lah pihak yang melakukan pelaporan karena secara hukum dia lah pihak yang mengalami kerugian.

Hal ini sesuai dengan Yurisprudensi Mahkamah Agung Nomor 183K/Pid/2010. Dalam Putusan Nomor 292/Pid.B/2014/PN.Rbi misalnya, perbuatan terdakwa KMA tidak dapat dikualifikasikan sebagai penghinaan karena ia tidak menyebutkan nama pelapor $\mathrm{N}$ dalam tanggapannya secara tertulis mengenai dugaan pelanggaran pemilihan umum di wall facebook. Demikian pula dalam Putusan Nomor 1933/ Pid.Sus/B/2016/PN.Mks, di mana terdakwa Y dibebaskan, karena dalam tulisannya di akun facebook miliknya tidak pernah menyebutkan nama terlapor SS.

Tidaksemuaputusanpengadilanmenerapkan indikator ini, misalnya Putusan Nomor 382/Pid. Sus/2014/Pn.Yky. Putusan ini keluar sebelum dilakukan amandemen atas Undang-Undang Informasi dan Transaksi Elektronik pada tahun 2016 yang secara tegas menyatakan bahwa Pasal 27 ayat (3) jo. Pasal 45 merupakan delik aduan. Meskipun demikian dalam pertimbangan hukum majelis hakim konstitusi pada Putusan Nomor 50/PUU-VI/2008 dan Nomor 2/PUUVII/2009 secara tegas menyatakan bahwa Pasal 310 KUHP merupakan genus crime dari Pasal 27 ayat (3) jo. Pasal 45 Undang-Undang Informasi dan Transaksi Elektronik, sehingga ketentuan ini harus dipandang sebagai delik aduan. Majelis hakim pada Putusan Nomor 382/Pid.Sus/2014/ Pn.Yky memasukkan pertimbangan hukum putusan Mahkamah Konstitusi tersebut. Oleh karenanya terdakwa FSS dinyatakan bersalah melakukan tindak pidana penghinaan meskipun 
dalam tulisannya di dalam akun path miliknya tidak disebutkan secara spesifik siapa yang ia hina.

Penyebutan nama pelapor dalam ucapan, tulisan atau pun gambar dalam beberapa putusan tidak menjadi syarat mutlak adanya penghinaan. Hal ini dikarenakan penyebutan nama pelapor disesuaikan isinya dan dilihat dari keadaankeadaan yang melatarbelakanginya, terutama yang berkaitan apakah penghinaan tersebut merupakan bentuk penghinaan materiel atau materiale belediging.

Majelis hakim dalam Putusan Nomor 196/ Pid.sus//2014/PN.BTL, memang terdakwa EEH menyebutkan nama Ayas yang merupakan nama panggilan dari pelapor DS, akan tetapi dilihat dari isi dan latar belakang terdakwa menulis tersebut merupakan bentuk penyampaian keluhan mengenai apa yang terjadi di kantor suami terdakwa. Begitu pula dalam Putusan Nomor 116/PID/2011/PT.DPS, di mana penyebutan nama terlapor ASK dalam tulisan terdakwa di facebook dilatarbelakangi oleh adanya potensi konflik dalam pengurusan gereja, dan perbuatan terdakwa yang menyebutkan terlapor sebagai kepala dua tidak bisa dikategorikan sebagai fitnah karena terdakwa dapat membuktikan apa yang ia sampaikan tersebut.

Disparitas antara tindak pidana yang diterapkan oleh majelis hakim yang berbeda untuk tindak pidana yang sama sebagaimana dalam 12 putusan tersebut. Hal ini terjadi karena adanya ketidakseragaman interpretasi hakim terhadap unsur-unsur dalam Pasal 27 ayat (3) jo. Pasal 45 Undang-Undang Informasi dan Transaksi Elektronik. Pada unsur dengan sengaja dan tanpa hak, perbedaan terlihat dari perdebatan mengenai penggunaan ajaran animus injuriandi serta bentuk dolus eventualis/opzet bij mogelijkheid- bewustzijn. Pada unsur mendistribusikan dan/ atau mentransmisikan dan/atau membuat dapat diaksesnya informasi elektronik dan/atau dokumen elektronik, perdebatan mengenai mana yang menjadi ruang privat dan ruang publik terutama di era online dan media sosial yang mengaburkan batas-batas antara ruang publik dan ruang privat.

Terakhir unsur penghinaan dan/atau pencemaran nama baik, yang masih ada jarak mengenai batasan perbuatan yang dikualifikasi unsur ini. Apakah unsur ini terpenuhi apabila ekspresi yang diungkapkan dalam perkataan dan tulisan tersebut harus menyebutkan secara jelas nama orang yang dihina atau dicemarkan nama baiknya. Perbedaan ini mempertegas permasalahan yang ada, yaitu tidak ada batas yang jelas mengenai tindakan apa yang dikualifikasi memenuhi unsur-unsur dalam Pasal 27 ayat (3) jo. Pasal 45 Undang-Undang Informasi dan Transaksi Elektronik dan mana yang tidak.

Pada akhirnya penafsiran yang berbedabeda atas unsur yang sama pada Pasal 27 ayat (3) jo. Pasal 45 Undang-Undang Informasi dan Transaksi Elektronik menimbulkan inkonsistensi dalam penerapan Pasal 27 ayat (3) jo. Pasal 45. Pengadilan di bawah Mahkamah Agung tidak memiliki standar dalam menentukan ekspresi atau perbuatan apa yang dikualifikasikan sebagai memenuhi unsur dalam Pasal 27 ayat (3) jo. Pasal 45 Undang-Undang Informasi dan Transaksi Elektronik atau tidak. Inkonsistensi ini berakibat pada aspek kebebasan berekspresi.

\section{B. Disparitas dalam Perlindungan Kebebasan Berekspresi}

Disparitasyangmenyebabkaninkonsistensi, tidak dapat dilepaskan dari rumusan undang- 
undang yang berlaku. Ini menjadi sumber tidak langsung dari disparitas dan inkonsistensi (KY RI, 2014: 185). Terdapat empat permasalahan dalam rumusan Pasal 27 ayat (3) jo. Pasal 45 UndangUndang Informasi dan Transaksi Elektronik yang menjadi ancaman dalam kebebasan berekspresi. Pertama, norma yang diatur dalam Pasal 27 ayat (3) jo. Pasal 45 Undang-Undang Informasi dan Transaksi Elektronik sama dengan beberapa pasal-pasal mengenai penghinaan dalam KUHP, dan ini merupakan bentuk overcriminalization .

Husak menyatakan bahwa overcriminalization salah satunya disebabkan adanya overlapping tindak pidana, yaitu ketika suatu kejahatan telah dinyatakan sebagai suatu tindak pidana oleh undang-undang yang ada, kemudian dikriminalisasi kembali dalam undang-undang lainnya (Husak, 2008: 36). Dalam praktiknya penegak hukum kerap mensubsiderkan Pasal 310 dan Pasal 311 KUHP dengan Pasal 27 ayat (3) jo. Pasal 45 UndangUndang Informasi dan Transaksi Elektronik.

Kedua, jika melihat dari rumusan pasal tersebut maka timbul kerancuan siapa yang hendak dipidana. Rumusan Pasal 27 ayat (3) jo. Pasal 45 Undang-Undang Informasi dan Transaksi Elektronik dapat diartikan dua perbuatan pidana, yaitu orang yang menyampaikan data atau informasi elektronik yang memuat penghinaan yang hendak dipidana, dan orang yang menyebarkan data atau informasi elektronik yang memuat penghinaan secara melawan hukum yang hendak dipidana.

Ketiga, penjelasan unsur "membuat dapat diakses" dalam penjelasan UndangUndang Informasi dan Transaksi Elektronik menimbulkan kerancuan karena perbuatan untuk menyebarkan suatu informasi elektronik dan/ atau dokumen elektronik kepada pihak lain atau publik selain dengan cara mendistribusikan dan mentransmisikan melalui sistem elektronik masuk dalam kategori ini. Hal ini membuka penafsiran bahwa selain cara-cara online, maka cara offline pun dapat dipandang sebagai perbuatan membuat dapat diakses.

Keempat, perumusan pasal tersebut mencampuradukkan tindak pidana penghinaan dengan tindak pidana pencemaran nama baik dan tindak pidana fitnah. Oleh karenanya perumusan tersebut bertentangan dengan tidak memenuhi kriteria standar tinggi, kejelasan, aksesibilitas, dan menghindari ketidakjelasan rumusan sebagaimana dimaksud dalam International Covenant on Civil and Politic Right. Permasalahan dalam perumusan ini menjadi ancaman bagi perlindungan hak atas kebebasan berekspresi di Indonesia.

Kebebasan hakim memegang berperan dalam penerapan rumusan Pasal 27 ayat (3) jo. Pasal 45 Undang-Undang Informasi dan Transaksi Elektronik. Ketika rumusan tersebut bermasalah, maka hakim sudah sepantasnya lebih berhati-hati dalam penerapannya dengan tidak hanya menjadi corong undang-undang saja. Memang konvensi internasional tidak secara tegas menempatkan penghinaan sebagai batasan atas kebebasan berekspresi, namun kebijakan hukum pidana Indonesia masih menghendaki kriminalisasi terhadap kejahatan penghinaan sebagai salah satu batasan atas kebebasan berekspresi.

Kebebasan berekspresi dibatasi oleh hak orang lain. Batasan yang dipergunakan selama ini adalah moralitas dan bahaya atau kerugian (harm) yang dihasilkan dari perbuatan menghina tersebut. Akan tetapi tidak ada garis yang jelas untuk memisahkan mana yang merupakan penghinaan dan mana yang bukan. Hal tersebut 
diserahkan sepenuhnya kepada majelis hakim. Pada akhirnya hakim lah yang menjadi pintu terakhir untuk perlindungan kebebasan berekspresi.

Dalam putusan-putusan yang dianalisis, ketidaktepatan perumusan Pasal 27 ayat (3) jo. Pasal 45 Undang-Undang Informasi dan Transaksi Elektronik dan kebebasan hakim dalam menginterpretasikan unsur-unsur pasal tersebut, membuat terjadinya inkonsistensi dalam perlindungan kebebasan berekspresi. Dari 12 putusan pengadilan yang dianalisis tersebut, hanya empat putusan yaitu: Putusan Nomor 1269/Pid. B/2009/PN.TNG; Putusan Nomor 390/Pid.B/2014/PN.Mks; Putusan Nomor 1832/ Pid.B/2012/PN.Jkt.Sel; dan Putusan Nomor 196/Pid.sus//2014/PN.BTL yang memberikan perlindungan kebebasan berekspresi pengguna internet.

Hakim dalam hal ini berhati-hati dalam menginterpretasikan dan menerapkan unsurunsur dalam Pasal 27 ayat (3) jo. Pasal 45 UndangUndang Informasi dan Transaksi Elektronik. Sebaliknya dalam Putusan Nomor 822K/Pid. Sus/2010; Putusan Nomor 324/Pid.B/2014/ PN.SGM; Putusan Nomor 196/Pid.sus//2014/ PN.BTL; Putusan Nomor 382/Pid.Sus/2014/ Pn.Yky; Putusan Nomor 292/Pid.B/2014/PN.Rbi; Putusan Nomor 33/PID.B/2014/PN.DPU; Putusan Nomor 116/PID/2011/PT.DPS; dan Putusan Nomor 1933/Pid.Sus/B/2016/PN.Mks, merupakan ancaman terhadap kebebasan berekspresi. Hakim dalam hal ini tidak tepat dan cermat menginterpretasikan unsur-unsur dalam Pasal 27 ayat (3) jo. Pasal 45 Undang-Undang Informasi dan Transaksi Elektronik.

Disparitas tersebut bahkan lebih condong menjadi ancaman atas kebebasan berekspresi bagi pengguna internet. Perkembangan teknologi yang cepat tanpa diikuti dengan perubahan pemikiran dari aparat penegak hukum terutama hakim, sehingga pasal penghinaan menjadi ancaman bagi kebebasan berekspresi. Hampir setiap tahun Komisi Hak Asasi Manusia Perserikatan Bangsa Bangsa dalam resolusinya tentang kemerdekaan berekspresi, selalu menyerukan keprihatinannya terhadap berlangsungnya penyalahgunaan dari ketentuan hukum mengenai tindak pidana penghinaan, karena ketentuan ini sering sekali dipergunakan untuk mengkebiri penyampaian kritik kepada pemerintah (Anggara et al., 2016: $3)$.

Perkembangan teknologi melalui sosial media menyebabkan apa yang disampaikan oleh warga negara kepada masyarakat bukan hanya mengenai pendapat atau kritik terhadap pemerintah, namun hal-hal yang menjadi percakapan sehari-hari. Dalam putusan-putusan pengadilan yang diteliti tersebut sebagian besar perkara tersebut berkaitan dengan penyampaian pendapat dan emosi atas kejadian sehari-hari, dan bukan kritik terhadap pemerintahan yang disampaikan secara online melalui media sosial.

Perkembangan teknologi membuat batas antara ruang publik dengan ruang privat menjadi kabur, demikian pula dengan perkembangan teknologi yang memberikan kemudahan bagi pengguna internet untuk menyebarkan ekspresi mereka dengan hanya menggunakan jari. Namun perkembangan ini belum diikuti dengan perubahan cara pandang aparat penegak hukum, terutama hakim. Akibatnya Pasal 27 ayat (3) jo. Pasal 45 Undang-Undang Informasi dan Transaksi Elektronik kerap kali dipergunakan untuk memidana penyampaian ekspresi dan emosi pengguna internet yang sesungguhnya tidak menimbulkan bahaya/kerugian yang signifikan, 
sebagaimana dalam Putusan Nomor 822K/Pid. Sus/2010; Putusan Nomor 324/Pid.B/2014/ PN.SGM; Putusan Nomor 196/Pid.sus//2014/ PN.BTL; Putusan Nomor 382/Pid.Sus/2014/ Pn.Yky; Putusan Nomor 292/Pid.B/2014/PN.Rbi; Putusan Nomor 33/PID.B/2014/PN.DPU; Putusan Nomor 116/PID/2011/PT.DPS; dan Putusan Nomor 1933/Pid.Sus/B/2016/PN.Mks.

\section{KESIMPULAN}

Berdasarkan hasil kajian yang dilakukan atas 12 putusan tersebut, maka dapat disimpulkan dua hal, yaitu:

1. Inkonsistensi penerapan Pasal 27 ayat (3) jo. Pasal 45 Undang-Undang Informasi dan Transaksi Elektronik terjadi karena disparitas dalam tindak pidana yang dijatuhkan oleh majelis hakim yang berbeda untuk tindak pidana yang sama. Disparitas tersebut terjadi karena terjadi perbedaan interpretasi atas unsur dengan sengaja dan tanpa hak; unsur mendistribusikan dan/ atau mentransmisikan dan/atau membuat dapat diaksesnya informasi elektronik dan/atau dokumen elektronik; dan unsur yang memiliki muatan penghinaan dan/ atau pencemaran nama baik, dalam Pasal 27 ayat (3) jo. Pasal 45 Undang-Undang Informasi dan Transaksi Elektronik. Inkonsistensi tersebut tidak jelas, bahkan menjadi semakin rancu mana ekspresi atau perbuatan yang dikualifikasikan sebagai unsur-unsur dalam Pasal 27 ayat (3) jo. Pasal 45 Undang-Undang Informasi dan Transaksi Elektronik tersebut.

2. Disparitas penerapan pasal penghinaan dalam Pasal 27 ayat(3) jo. Pasal 45 UndangUndang Informasi dan Transaksi Elektronik menyebabkan terjadinya inkonsistensi dalam perlindungan kebebasan berekspresi pengguna internet di Indonesia. Hal tersebut dikarenakan ketidakjelasan perumusan Pasal 27 ayat (3) jo. Pasal 45 Undang-Undang Informasi dan Transaksi Elektronik, dan kebebasan hakim dalam menginterpretasikan unsur-unsur Pasal 27 ayat (3) jo. Pasal 45 tersebut. Pada akhirnya inkonsistensi ini cenderung mengarah pada ancaman terhadap kebebasan berekspresi.

\section{DAFTAR ACUAN}

Adji, I.S. (2001). Kebebasan pers: Tuntutan kebebasan absolut? Jakarta: Kantor Pengacara dan Konsultan Prof. Oemar Seno Adji SH. dan Rekan.

(2008). Hukum \& kebebasan pers. Jakarta: Diadit Media.

Anggara, et al. (2016). Menimbang ulang Pasal 27 ayat (3) UU ITE dalam putusan pengadilan pertimbangan putusan pengadilan terkait penggunaan Pasal 27 ayat (3) UU No. 11 Tahun 2008 tentang Informasi dan Transaksi Elektronik di Indonesia. Jakarta: Institute for Criminal Justice Reform.

Balkin, J.M. (2004). 'Digital speech \& democratic culture: A theory of freedom of expression for the information society.' New York University Law Review, 79(1), 1-55.

Chan-Olmsted, S.M., Cho, M., \& Lee, S. (2013). 'User perceptions of social media: A comparative study of perceived characteristics \& user profiles by social media.' Journal of Communication and Media Technologies, 3(4), 149-178. 
Hiariej, E.O.S. (2014). Prinsip-prinsip hukum pidana. Yogyakarta: Cahaya Atma Pustaka.

Husak, D. (2008). Overcriminalization the limitation of criminal law. New York: Oxford University Press.

Ibrahim, J. (2013). Teori \& metodologi penelitian hukum normatif. Malang: Bayumedia.

Komisi Yudisial Republik Indonesia (KY RI). (2014). Disparitas putusan hakim: Indikasi \& implikasi. Jakarta: Sekretariat Jenderal Komisi Yudisial Republik Indonesia.

Mahmud, P. (2005). Penelitian hukum. Jakarta: Prenadamedia Group.

Muladi. (2002). Hak asasi manusia, politik, \& sistem peradilan pidana. Semarang: Badan Penerbit Universitas Diponegoro.

Prahassacitta, V. (2017). 'Citizwn journalism in cyber media: Protection \& legal responsibility under Indonesian Press Law.' Journal Humaniora, 8(1), 45-56.

Prodjodikoro, W. (2003). Tindak pidana tertentu di Indonesia. Bandung: PT Refika Aditama.

Remmelink, J. (2003). Hukum pidana komentar atas pasal-pasal terpenting dari Kitab UndangUndang Hukum Pidana Belanda \& padanannya dalam Kitab Undang-Undang Hukum Pidana Indonesia. Jakarta: PT Gramedia Pustaka Utama.

Rezaldi, M. (2015). Anatomi putusan perkara pencemaran nama baik melalui media internet No. Registrasi Perkara 1333/Pid.Sus/2013/ PN.JKT.SEL. (Terdakwa Benny Handoko). Jakarta: MaPPI FH UI.

Smith, R.K.M, et al. (2008). Hukum \& hak asasi manusia. Yogyakarta: PUSHAM UII.
Soesilo, R. (1996). Kitab Undang-Undang Hukum Pidana (KUHP) serta komentarnya lengkap pasal demi pasal. Bogor: Politeia. 